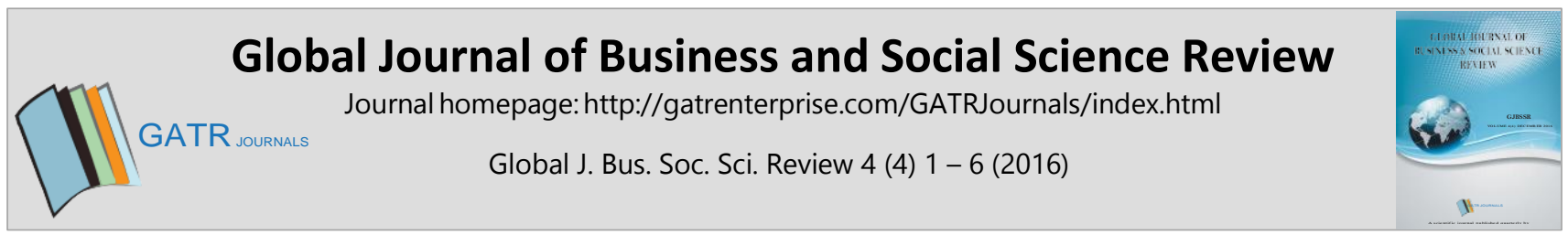

\title{
The Future of Service Learning in International Education
}

\author{
Andrew J. Bolt ${ }^{1^{*}}$ and Pandora Rupert ${ }^{2}$ \\ ${ }^{1,2}$ Fort Hays State University/Shenyang Normal University, 600 Park St., 67601, Hays, KS, USA
}

\begin{abstract}
Objective - This paper explores the complex dynamics of teaching service learning to EFL learners at a Chinese university through the eyes of two international instructors from an American partner school. By reflecting on different cultures' views on charity and assistance through tools like the World Giving Index, educators can gain a deeper understanding of the implications of international perspectives on service work. Tailoring pedagogical approaches to local conditions can better fulfill service education's function of producing future leaders who make cooperation and altruism a larger priority.

Methodology/Technique - The paper examines previous studies and reports.

Findings - The finding shows that perception of Western-style educational charities remains low as insisting on this can be met with a lack of enthusiasm and even hostility. But from international perspective, increasing number of students are likely to spend some of their educational experience abroad.

Novelty - Providing previous context and world statistics, it gives reason on initiating service learning and its contribution on solving global, humanitarian and environmental issues.
\end{abstract}

Type of Paper: Review

Keywords: Developing Nations; Global Partnerships; International Education; Service Education; Service Learning.

JEL Classification: M10, M19, M29.

\section{Introduction}

Education has become an increasingly globalized endeavor over the last few decades. In the United States alone, 886,052 international students took part in the 2013/2014 school year (Institute of International Education, 2014a), and programs like the Generation Study Abroad initiative spearhead by the Institute if International Education (2014b) aims to double the number of students the U.S. sends abroad by 2018. As students and institutions finding increasing benefit in a more international perspective, so too do international problems arise. The massive changes in technology, environment, and geopolitics in the last few decades, present problems that require a wider knowledge base and a more global perspective to help solve. These problems are the purview of service learning, a discipline focused on preparing students to assist where they are most needed. Researchers agree that the ideals of educating primarily for self-survival has some serious drawbacks, and service outreach is imperative (Giacalone \& Thompson, 2006; Ghoshal, 2005; Mintzberg, 2004; Pfeffer \& Fong, 2002; Broberg \& Krull, 2010; Coldwell, Joosub, \& Papageorgiou, 2012). Service learning as an educational focus encourages

\footnotetext{
* Paper Info: Revised: September 3, 2016

Accepted: October 17, 2016

* Corresponding author:

E-mail: andrewjbolt@gmail.com

Affiliation: Fort Hays State University/Shenyang Normal University, USA.
} 
students to acknowledge and work with underserved populations in their community while reflecting and gaining knowledge through the experience (Corroto, 2014). Service learning is not relegated to one field or program, and it can be found across university campuses in the curriculum of business, leadership, civic engagement, and elsewhere (Chuang \& Chen, 2013). In an international context, the needs are requirements of service education become even more elastic, as differing ideas and opinions between countries, within countries, and even between instructor and student can produce widely disparate understandings of the appropriate way to solve problems and engage with the larger community.

\section{International Perspectives on Giving: China and the United States}

Promoting service learning as an educational discipline first requires an understanding of current, prevailing conceptions of charity. The United Kingdom-based Charitable Aid Foundation releases an annual report based on Gallup polls called The World Giving Index (WGI), which provides a useful place to start. This index ranks over 130 countries in the world with the aim of providing insight into the scope and nature of giving around the world. In 2015, the WGI found, for example, that China ranks at 128 on the index of charitable giving, in the bottom $10 \%$ of ranked nations. The factors that make up this ranking include the number of people who say they gave money or volunteered their time to charitable organizations, as well as how many reported helping a stranger in a typical month. The three behaviors are also examined individually within the report. Regardless of whether or not this is an accurate representation of each nation's charitable spirit, which will be discussed in more detail below, the WGI provides an overview of how Western nations typically evaluate charity and service. Of particular note is the fact that all three dimensions are primarily measures of individual giving, asking what a single person has done in the last year that might be qualified as a charitable contribution to society.

Other research has focused on charitable giving as a larger organizational activity. For instance, Hess, Rogovsky and Dunfee, (2002) found that in the United States, volunteer programs for corporate employees are more valued by the community than donations of large sums of money. In China, political affiliations have a significant impact on corporate giving (Song \& Wu, 2015), especially because political connections help firms secure favorable regulatory conditions and gain access to assets such as bank loans (Agrawal \& Knoeber, 2001). There is considerable research done that confirms how political relationships increase Chinese corporate philanthropy (Li \& Zhang, 2010; Aronson, Wilson, \& Akert, 2005; Bartkus, Morris, \& Seifert, 2002), and corporate philanthropy plays an important role in cultivating a good relationship with the government and achieving political legitimacy (Wang \& Qian, 2011). Furthermore, Chinese authorities often rely on and strongly encourage corporate giving because with China's rapid pace of development, government resources are often taxed by large-scale community and social welfare projects. Under these conditions, corporate contributions become a means to alleviate resource shortages (Dickson, 2003). Brown, Helland, and Smith (2006) found that politically connected firms get more government support and are more likely to become involved in philanthropy as a response to government efforts, with the aim of being viewed in a more positive light in the future. Research shows that although change can be slow, Chinese firms are trying to expand the scope of corporate philanthropy to community service and cause-related marketing activities (Amato \& Amato, 2007).

Yet for the average Chinese citizen, admitting to one's own need can be considered shameful or an unacceptable sign of weakness. In a situation like this, individual, one-on-one "charity" in China is less likely to go through formal organizations. Lim and Lim (2013) suggest that services such as counseling those in need are more likely to be accepted when they are informal, personal, or largely anonymous. The idea of friends doing favors for friends offers a different context than western ideas of helping the less fortunate, which calls more attention to the power imbalance in the relationship. In a situation like this, tools like the WGI are potentially less useful for evaluating cultures that have different beliefs about the nature and purpose of volunteer service or giving. 


\section{Service Learning in the Classroom}

This attitude towards giving or accepting charity has obvious implications for how service is measured and classified across cultures. Service learning is often experiential learning, where the student engages in their community through advocacy, participation, and conversation. It addresses human and community needs with structured opportunities to promote student learning and development through preparation, action reflection and assessment (Dumas, 2002). In order to do this in any meaningful way, it is important that the educator first understand the prevailing attitudes of local students. It Chinese students attending the authors' classes at Shenyang Normal University, tasked with designing and implementing field work projects for service learning classes, often express reluctance to engage in Western-style charity work.

As one student said of an elementary school to whom she was contemplating offering assistance, "If I go to them and offer to help with all their problems of poverty, they will think I am telling them that being poor is shameful." Simple differences in phrasing often have a large effect on enthusiasm and attitude toward service learning tasks. Helping out at an overcrowded classroom becomes more about getting to work with bright kids than about taking a burden off the teacher, planting trees becomes more about increasing beauty than solving the problems of overdevelopment, and so forth.

Western educational methods often focus on individuals solving problems, and from that perspective, cultures that have different views on direct criticism and the assignment of blame can appear to be ignoring the issue or unwilling to face the reality of the situation. Meanwhile, even well-intentioned Western discussions of issues can seem unnecessarily harsh and accusatory to Chinese audiences. Regardless of what tradition a service learning student or educator operates under, attempting to force a class to completely rewrite their cultural context in order to begin executing basic tasks seems unlikely to succeed. Instead, if service learning is to be taught in an international context, it needs to be presented with regard to the local concepts of useful action. It is therefore necessary for service learning educators to develop a stronger awareness of the local community's needs and conceptions of charity, as well as connecting local conditions to larger world issues, such as those presented by the United Nations Millennium Development Goals (MDGs).

\subsection{The Millennium Development Goals}

The United Nations' Millennium Development Goals were originally developed in 2000 with the aim of making significant progress on world issues by 2015 . They include eradicating extreme poverty, increasing primary education, promoting gender equality, reducing child mortality, improving maternal health, eradicating AIDs and other diseases, ensuring environmental stability, and promoting global partnership. Since inception, awareness about the goals have improved the lives of humans around the globe considerably. For example, statistics from the United Nations' Development Program (UNDP) reveal that number of people in extreme poverty declined by more than half in a twenty-five-year period, falling from 1.9 billion in 1990 to 836 million in 2015. The proportion of undernourished people in the world's developing regions showed a similar decline, dropping by almost $50 \%$ in the same period. The number of out-of-school children of primary school age worldwide fell to an estimated 57 million in 2015, down from 100 million in 2000 (United Nations Development Programme, 2015). In addition, recently, seventeen new goals have been created with a 2030 target date. The goals are meant to create three dimensions of sustainable development: environmental, social, and economic. The importance of these three topics is paramount to college-aged students of all cultures. Contextualizing service learning in terms of these UN goals provides a way to teach service learning with a less culturally narrow focus. Chinese students can focus on building ethical companies or working in close-knit communities, and Western students can continue to volunteer for larger charitable organizations while still working toward common goals like ending pollution or reducing poverty. Since the focus comes from the UN, the discussion is necessarily international, but the without the implicit, potentially imperialistic overtones of trying to force students to focus on one culture's solutions over another. 
Ultimately, the benefits of the service learning approach include instilling altruism as a core value in learners, personal satisfaction, professional development, and improved mental and emotional flexibility (Flinders, 2013). Generally speaking, service learning students in international courses at Shenyang Normal University start from a simple idea for personal change. Initial suggestions proposed have included translating menus into English to help foreign visitors or reusing laundry water to conserve resources. Often, these ideas show potential and a desire to help with a real issue, but they are notably personal and often do not involve advocacy or getting others in the community involved in either the development or execution stage. These ideas are often engaging starts, but not necessarily the kind of long-term approach or obvious avenue toward future community involvement that might define a service leader. The authors have found that engaging in broader service activities actually helps narrow the focus and strengthen the projects. By introducing students to the United Nations Millennium Development Goals, students are focused toward thinking of their local situation in terms of international issues. In this context, service ideas typically shift from personal projects that could be done on the student's own time to those that require more direct interaction with those in need. This is often more rewarding for students because they receive immediate positive feedback during the process of helping others away from the relatively disconnected world of academic praise. Community activity-based projects have included partnering with schools in a low income village to do things like raising funds to improve local play equipment and helping the students learn English or improve their math skills. Presenting these ideas in the context of the MDGs gave students a way into the conversation that felt less overtly critical and more about working with the school to achieve long-term, international goals. Projects with a focus on the MDG goals instill in students a personal investment in broad service outcomes, and students learn firsthand how they can make a difference. One student team was able to see their local impact in terms of the MDGs at that impoverished village kindergarten. The kindergarten had an 8square-meter lump of dirt, which served as the play area. After the team discussed their UN objectives and matched them to the kindergarten's needs, they saw that they could raise the needed funds to improve the play area. The students were now very excited. Not only were they helping their community, they were able to understand that their project had world implications as they were helping to advocate for UN Goal \#1 "Eradicate Poverty." After their project was finished, the kindergarten play area had a cement foundation, a small sandbox and several toys for the younger students. Meanwhile, the older students revealed that their summer plans had changed, and they were going to join a service organization called Gap Year which matches students to service projects. By focusing the service learning curriculum on the MDGs, teachers encourage students to engage in a world dialogue surrounding civic improvement.

The authors have found that looking to the United Nations' top global concerns not only excites students but makes them aware that they can engage as part of a global service network. Regardless of whether they are writing an analytical essay about the necessity of green technology or undertaking a fieldwork project to help with recycling initiatives, the students are inspired to think more about others in new ways and approach broader global issues from their unique personal and cultural perspectives. When the students are assigned a specific goal of the 'world,' so to speak, the energy and enthusiasm reaches a crescendo. Suddenly, they become players in a global stage, stakeholders in a global conversation, and learners who can think locally and act globally. The students' focus moves from short-term solutions to long-term outcomes. When the connection between local community action and larger world events inspires thought and action, the students engage with the true meaning of service learning. The cease to see the advocacy they embark on as limited and perfunctory, especially when they understand they are part of a bigger effort that involves all countries and all citizens of the world. As a result, students have a different view of approaching a poverty-stricken village in their community, even as their approach remains rooted in their own belief systems. Focus on the teamwork and connection that defines collectivist approaches to problems-solving, those villages became valuable for what they add to the world's story, and students become willing to converse, interview, engage, and listen to solutions and concerns rather than becoming preoccupied with fear of embarrassing themselves or others by focusing on the negative.

\section{Conclusion}


Ultimately, sensitivity to how different cultures view their larger obligations to the world is important in running a successful service learning program for a globalized world. In China, for example, perceptions of organized, Western-style charities remain low following a series of scandals and a lack of transparency (Burkitt, 2015; Jiang, 2013). In such an environment, insisting on Western-style volunteerism can be meet with a lack of enthusiasm and even hostility. As research continues on international education and an increasing number of students are likely to spend some of their educational experience abroad, increased research is needed into the best methods for incorporating the local conditions into meaningful engines of international service learning. One of possible method involves using the UN Millennium Development Goals as a jumping off point, especially when they are encouraged to think of them as something in which they have a personal and national stake. It may be that servicelearning education cannot meaningfully be taught across cultures unless educators re-examine how they approach the subject, contextualize, and present the topic. Courses need to focus not just on getting students to volunteer their time and effort, but to consider how volunteerism is construed and what may result in the best possible learning outcomes given the local conditions.

Without further research regarding cultural views on giving and the effectiveness of service learning practices in international context, it will be impossible to develop workable international education programs. The primary value of the MDG is that, when properly presented, they excite students, lessen apathy, and provide a grassroots approach to getting students off their seats and into conversations and international advocacy efforts. Further research is required to determine if the MDGs would be successful in similar courses outside of China or the U.S., but their basic function of encouraging students to think of their culturally distinct communities and approaches toward giving in terms of the larger world community has implications for service learning programs around the globe.

\section{References}

Agrawal, A., \& Knoeber, C. R. (2001). Do some outside directors play a political role? Journal of Law and Economics, 44, 179. Retrieved from http://www.press.uchicago.edu

Amato, L. H., \& Amato, C. H. (2007). The effects of firm size and industry on corporate giving. Journal of Business Ethics, 72, 229-241. Retrieved from http://www.springer.com

Aronson, E., Wilson, T. D., \& Akert, R. M. (2005). Social psychology (5th ed.). Upper Saddle River, NJ: Prentice Hall.

Broberg, T. and Krull, P. (2010). Where creativity and innovation go to school. Journal of Corporate Citizenship, 39, 57-86. Retrieved from http://www.greenleaf-publishing.com/

Brown, W. O., Helland, E., \& Smith, J. K. (2006). Corporate philanthropic practices. Journal of Corporate Finance, 12, 855-877. Retrieved from

Bringle, R. G., Hatcher, J. A., Hamilton, S., and Young, P. (2001)."Planning and Assessing Campus/Community Engagement." Metropolitan Universities, 2001, 12(3), 89-99.

Burkitt, L. (2015, April 1). Nine out of 10 Chinese charities fail transparency test, report finds. Wall Street Journal. Retrieved from www.wsj.com

Chuang, K., \& Chen, K. (2013). Designing service learning projects in system analysis and design course. Academy of Educational Leadership Journal, 17(2), 47-60. Retrieved from http://www.alliedacademies.org

Coldwell, D. D., Joosub, T. T. and Papageorgiou, E. E. (2012). Responsible leadership in organizational crises: An analysis of the effects of public perceptions of selected SA business organizations' reputations. Journal of Business Ethics, 109(2) 133-144. Retrieved from http://www.springer.com

Corroto, C. (2014). When you have a hammer in your hand, everything looks like a nail: The architecture of service learning. Qualitative Research Journal, 14, 103-118. Retrieved from http://qrj.sagepub.com

Dickson, B. J. (2003). Red capitalists in China: The party, private entrepreneurs, and prospects for political change. Cambridge: Cambridge University Press.

Dumas, C. (2002). Community-based service-learning: Does it have a role in management education? International Journal of Value - Based Management, 15, 249-264. Retrieved from http://www.springer.com/social+sciences/applied+ethics/journal/10774 
Flinders, B. A. (2013). Service-learning pedagogy: Benefits of a learning community approach. Journal of College Teaching \& Learning (Online), 10,159. Retrieved from http://www.cluteinstitute.com

Ghoshal, S. (2005). Bad management theories are destroying good management practices. Academy of Management Learning \& Education, 4, 75-91. Retrieved from http://www.scimagojr.com

Giacalone, R.A. and Thompson, K. R. (2006), Business ethics and social responsibility education: Shifting the worldview, Academy of Management Learning \& Education, 5(3), 122-125. Retrieved from http://www.scimagojr.com

Hess, D., Rogovsky, N., \& Dunfee, T. W. (2002). The next wave of corporate community involvement: Corporate social initiatives. California Management Review, 44(2), 110-125. Retrieved from http://cmr.berkeley.edu

Jiang, C. (2013, September 25). Chinese deterred from donating to their country's dubious charity sector. Time. Retrieved from www.world.time.com

Li, S., Song, X., \& Wu, H. (2015). Political connection, ownership structure, and corporate philanthropy in china: A strategic-political perspective. Journal of Business Ethics, 129, 399-411. doi:10.1007/s10551-014-2167 $\mathrm{y}$

Li, W., \& Zhang, R. (2010). Corporate social responsibility ownership structure, and political interference: Evidence from China. Journal of Business Ethics, 96, 631-645. Retrieved from http://www.springer.com

Lim, B. K. \& Lim, S. L. (2013). Counseling in China. In T. H. Hohenshil, N. E. Amundson, \& S. G. Niles (Eds.). Counseling around the world. Alexandria, VA: American Counseling Association.

Mintzberg, H. (2004), Managers not MBAs: A hard look at the soft practice of management andmanagement development. San Francisco, CA: Berrett-Koehler Publishers.

Pfeffer, J. \& Fong, C. T. (2002). The end of business schools? Academy of Management Learning \&Education, 1, (1)78-95. Retrieved from http://www.scimagojr.com

United Nations Development Programme. (2015). Millennium development goals report. Retrieved from http://www.us.undp.org

Wang, H., \& Qian, C. (2011). Corporate philanthropy and corporate financial performance: The roles of stakeholder response and political access. Academy of Management Journal, 54(6), 1159-1181. Retrieved from http://aom.org/amj/

World giving index. (2015). Retrieved from www.cafonline.org 